\title{
SPEI ve SPI İndisleri Kullanılarak İstanbul-Damlıca Deresi Havzasında Kuraklık Șiddetlerinin Analizi
}

\author{
Fatih BAKANOĞULLARI*
}

Atatürk Toprak, Su ve Tarımsal Meteoroloji Araștırma Enstitüsü, Kırklareli

*Sorumlu yazar e-mail (Corresponding author e-mail): fbakanogullari@gmail.com Geliș tarihi (Received) : 16.05.2019

Kabul tarihi (Accepted): 20.08.2019

DOI: $10.21657 /$ topraksu. 566693

\section{Öz}

Klimatolojik kaynaklı afetlerin içinde kuraklık en karmașık ve hasar veren bir olaydır. Kurak ve yarı kurak bölgelerde yağıș, tarımsal üretimi kontrol eden en önemli faktördür. Türkiye'de de bazı bölgelerde kuraklık sorunu kendini özellikle tarım sektöründe ve ekosisteme yaptığı etkiler ile göstermektedir. Bu çalıșmanın amacı İstanbul-Büyükçekmece içme suyu havzasında yer alan Damlıca deresi havzasında 1982-2006 yılları arası havzada ölçülmüș meteorolojik veriler kullanılarak kuraklığın sıklığı ve șiddetinin Standartlaștırılmıș Yağıș Evapotranspirasyon İndisi (SPEI) ile belirlenmesi ve Standartlaștııılmıș Yağıș İndisi (SPI) ile karșılaștııımasıdır. SPEI kuraklık indisi evapotranspirasyonu Thornthwaite eșitliği ile tahmin etmektedir. 25 yıllık veri seti ile yıllık SPEI ve SPI İndeksleri arasındaki regresyon analizinde, ikinci derece polinoma göre yıllık SPI ve SPEI kuraklık indeksleri arasında determinasyon katsayıSI $\left(R^{2}\right) 0.977$ olarak belirlenmiș ve istatistiksel olarak anlamlı bulunmuștur. Ancak aylık, mevsimlik ve 6 aylık kuraklık değerlendirmelerinde kuraklık șiddetleri arasında farklar görülmüștür. Yıllık değerlendirme sonuçlarına göre; SPEl indisi ile havzada 4 yll orta kurak (1983, 1989, 2004, 2006), 7 yll hafif kurak (1982, 1992, 1993, 1994, 1999, 2000, 2003), SPI indisi ile ise 2 yıl șiddetli kurak (1983, 1989), 3 yıl orta kurak (1982, 2004, 2006) ve 2 yıl hafif kurak (1992, 1993) yıl olarak tespit edilmiștir. Tarımsal üretim açısından yağıș, sıcaklık ve evapotranspirasyon verileri ile hesaplanan SPEI kuraklık indisi tarımsal üretim ve kuraklık değerlendirmelerinde daha hassas sonular verdiği için kuraklığın azaltılması politikalarında karar vericilere daha sağlıkı sonuçlar verebilir.

Anahtar Kelimeler: Damlıca deresi havzası, kuraklık, standartlaștırılmıș yağıș evapotranspirasyon indisi (SPEI), standartlaștırımıș yağıș indisi (SPI), İstanbul

\section{Analysis of Drought Intensity Using SPEI and SPI Indices in Damlıca Watershed-istanbul, Turkey}

\begin{abstract}
Drought is the most complex and damaging event in climatic disasters. Precipitation is the most important factor to control agricultural production in arid and semi-arid regions. The problem of drought in some regions in Turkey shows itself especially effect on the ecosystem and agriculture. The aim of this study is to determine the frequency and severity of drought with Standardized Precipitation Evapotranspiration Index (SPEI) and compare with Standardized Precipitation Index (SPI) using meteorological data measured between 1982 and 2006 in Damlica creek basin located in
\end{abstract}


Istanbul-Buyukcekmece drinking water basin. The SPEI drought index estimates evapotranspiration with Thornthwaite equation. In the regression analysis between the 25-year data set and the annual SPEI and SPI indices, the coefficient of determination (R2) between the annual SPI and SPEI drought indices according to the second order polynomial was found to be 0.977 and found to be statistically significant. However, there were differences between drought severities in monthly, seasonal and 6-month drought periods. According to the annual evaluation results; SPEI Index was determined as 4 years of moderate drought $(1983,1989,2004,2006), 7$ years of mild drought $(1982,1992,1993$, 1994, 1999, 2000, 2003), and SPI index was found as 2 years of severe drought (1983, 1989), 3 years of moderate drought $(1982,2004,2006)$ and 2 years of mild drought $(1992,1993)$. The SPEl drought index calculated by precipitation, temperature and evapotranspiration data may give healthier results to policy makers in drought mitigation policies in terms of giving more accurate results in agricultural production and drought assessments.

Keywords: Damlıca creek watershed, drought, İstanbul, standardized precipitation evapotranspiration index (SPEI), standardized precipitation index (SPI)

\section{Giriș}

Çevre koșullarından özellikle yağıș miktarı ve yetiștirme mevsimi içindeki dağılıșında yıldan yıla görülen değișimler Trakya Bölgesi'nde bitkisel üretimde ve verimlerinde önemli değișimlere neden olmaktadır. Toplam yağıș yeterli olsa bile yağıș dağıımının düzensiz olması verim potansiyeli yüksek genotiplerin de performanslarının düșmesine neden olabilmektedir. Mevcut su kaynaklarının yetersizliği ve küresel ısınmanın gözlenen ve beklenen olumsuz etkileri Trakya Bölgesi'nde tarımı yapılacak genotiplerin seçiminde kurağa dayanıkılık ve etkin su kullanım yeteneğinin temel özellikler olarak ele alınmasını zorunlu kılmaktadır. Kuraklık etkisi nedeniyle kalite ve verimde ortaya çıkacak azalma ve bozulmalar özelde bölge ve genelde ülke ekonomisini olumsuz etkileyecektir. Bitkisel üretimde birim alandan elde edilecek gelirin azalması Trakya topraklarının tarım dıșı amaçlarla kullanılmasını daha da hızlandıracaktır. Böylece, var olan çevre sorununun boyutu daha da genișleyecektir. Kuraklık her yıl dünyada fazla sayıda insanı etkileyen ve dünyanın en maliyetli afetlerindendir (Wilhite, 2000). Aynı zamanda, Kuraklıklar çevresel bir felaket olarak belirtilmektedir. Bazı çalıșmalarda yağıșlardaki eksikliklerin elverișli su kullanım kapasitesinde de azalmalara sebep olduğundan bahsedilmektedir (Rossi, 2000; Wilhite, 2000; Koustroulis, vd., 2011). Kuraklığın yağıșa, toprak nemine ya da potansiyel evapotraspirasyona dayalı değișik tanımları vardır (Wilhite, 1985; Heim, 2002; Svoboda vd., 2002; Türkeș, 2014; Türkeș, 2017; Türkeș, 2019).

Genel olarak kuraklık, bir yörede yağıșın, yer altı veya yüzey sularının, iklim olarak beklenen miktardan (ortalamadan) daha az olduğu süreler olarak tanımlanmaktadır. Kurakııksıcaklıkartıșile doğru, yağıș artıșı ile ters orantılıdır (Çaldağ vd., 2004). Kuraklık; meteorolojik, tarımsal, hidrolojik ve sosyoekonomik olarak sınıflandırımaktadır. Standartlaștırılmıș Yağıș Indisi (SPI) meteorolojik kuraklığın șiddetini belirlemek için genel olarak kullanılmaktadır. SPI, uzun dönem yağıș kayıtlarının normal dağılıma dönüștürülmesi ve uygulanması temeline dayanmakta ve bu indeks ile farklı zaman dilimlerinde kurak ve nemli süreler hesaplanmaktadır (Dai, 2011). Standartlaștırılmıș Yağıș Evapotranspirasyon İndisi (SPEI) bitkinin bulunduğu ortamdaki evapotranspirasyonu ve meteorolojik kuraklığı dikkate alarak tarımsal kuraklık șiddetinin değerlendirilmesi için geliștirilmiștir (Vicente-Serrano, 2010). Meteorolojik ve Tarımsal kuraklığın belirlenmesinde SPI ve SPEI indeksleri kullanılarak farklı araștıııılar tarafından kuraklığın yersel ve zamansal dağılımının analizi, izlenmesi, indekslerin karșılaștırılması gibi konularda çalıșmalar yürütülmüștür (Wilhite vd., 2007; Türkeș ve Tatlı, 2009; Kwak vd., 2013; Yürekli ve Ünlükara, 2013; Nedealcov vd., 2015; Stagge vd., 2015; Gümüș vd., 2016; Keskiner vd., 2016; Camalan vd., 2017; Tong vd., 2017; Aksoy vd., 2018; Bae vd., 2018; Chen vd., 2018; Çetin vd., 2018, Keskiner vd., 2019).

Bu çalıșmada; İstanbul-Büyükçekmece gölü su toplama havzasında yer alan uzun yıllar (19822006) hidrolojik ve meteorolojik ölçümlerin yapıldığı Damlıca deresi araștırma havzasında (Șekil 1) iki kuraklık İndeki ile meteorolojik ve tarımsal kuraklığın farklı zaman dilimlerinde (aylık, mevsimlik, 6 aylık ve yıllık) kuraklık șiddetlerini belirlenmiș ve analizi yapılmıștır. 


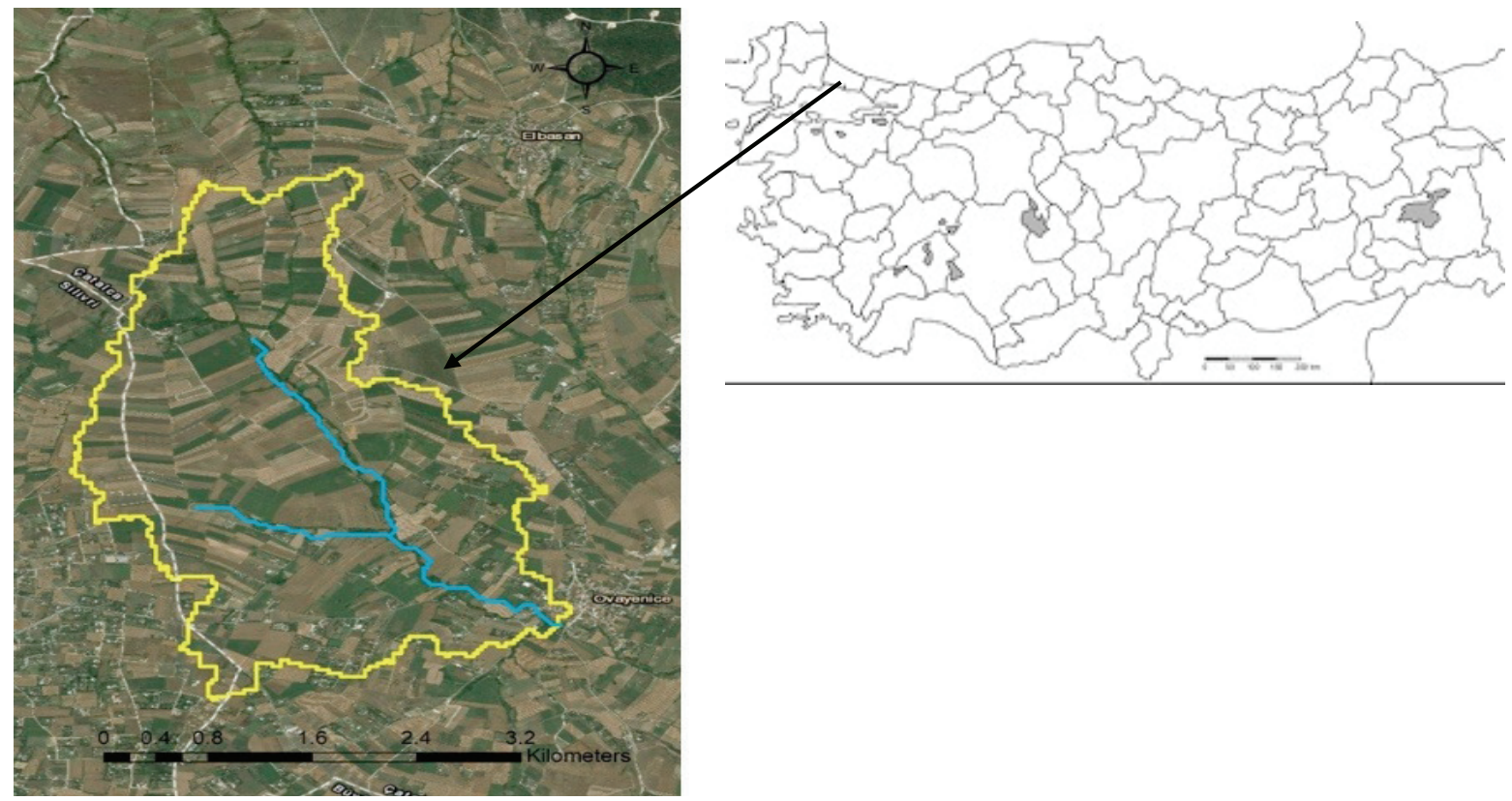

Sekil 1. Damlıca deresi havzası haritası ve ülkesel konumu

Figure 1. Damlica creek watershed map and location of country

\section{MATERYAL VE YÖNTEM}

Araștırma havzası, Çatalca ile Kumburgaz yolu topoğrafik haritası incelendiğinde, suyolları üzerinde, Kumburgaża 9 km, İstanbul'a ise 51 km açısından, iki tane 2. dereceden kolun Damlıca mesafededir. Havza alanı 8.26 km² dir. Havzanın Deresine bağlandığı ve Damlıca Deresinin 3

Çizelge 1. Damlıca deresi havzası aylık ortalama yağıș $(\mathrm{mm})$ verileri.

Table 1. Monthly average rainfall $(\mathrm{mm})$ data of Damlica creek watershed.

\begin{tabular}{ccccccccccccc}
\hline YII & Oca. & Sub. & Mar. & Nis. & May. & Haz. & Tem. & Ağu. & Eyl. & Eki. & Kas. & Ara. \\
\hline 1982 & 84.8 & 24.4 & 59.7 & 85.7 & 36.6 & 11.5 & 48.8 & 21.5 & 5.9 & 31.6 & 35.7 & 112.3 \\
1983 & 77.9 & 49.5 & 5.5 & 21.5 & 33.8 & 82.1 & 47.5 & 53.8 & 9.0 & 38.7 & 60.7 & 39.5 \\
1984 & 99.2 & 62.1 & 96.0 & 80.3 & 21.9 & 47.5 & 38.8 & 74.9 & 2.1 & 58.4 & 38.3 & 44.5 \\
1985 & 189.9 & 83.4 & 52.0 & 39.5 & 1.3 & 24.7 & 11.3 & 1.1 & 13.5 & 109.4 & 137.2 & 64.1 \\
1986 & 158.9 & 69.8 & 21.2 & 51.6 & 0.4 & 45.6 & 6.6 & 0.0 & 25.3 & 116.4 & 43.6 & 96.7 \\
1987 & 159.7 & 34.6 & 241.2 & 74.0 & 33.8 & 25.3 & 54.0 & 35.0 & 21.4 & 37.7 & 107.3 & 182.0 \\
1988 & 33.7 & 53.8 & 61.0 & 76.3 & 15.0 & 65.1 & 52.6 & 0.0 & 23.8 & 75.6 & 194.6 & 184.9 \\
1989 & 25.7 & 5.4 & 72.1 & 10.4 & 77.4 & 30.4 & 0.0 & 15.0 & 8.7 & 38.3 & 107.9 & 115.6 \\
1990 & 13.6 & 44.2 & 12.4 & 53.3 & 58.4 & 47.1 & 0.0 & 6.7 & 60.3 & 58.7 & 117.3 & 203.5 \\
1991 & 23.4 & 42.0 & 51.3 & 105.8 & 109.2 & 18.7 & 44.6 & 27.6 & 99.8 & 206.7 & 47.3 & 46.7 \\
1992 & 14.6 & 12.3 & 80.3 & 53.0 & 18.4 & 46.3 & 69.4 & 3.7 & 11.6 & 72.5 & 72.2 & 137.0 \\
1993 & 66.8 & 77.7 & 47.5 & 40.4 & 77.3 & 2.1 & 3.4 & 32.6 & 26.3 & 3.7 & 140.1 & 98.2 \\
1994 & 47.5 & 37.4 & 37.9 & 31.4 & 48.6 & 66.3 & 86.1 & 4.2 & 0.0 & 65.4 & 92.9 & 119.6 \\
1995 & 154.7 & 59.5 & 94.0 & 43.2 & 12.5 & 33.6 & 106.7 & 12.9 & 72.1 & 32.3 & 111.8 & 85.7 \\
1996 & 35.3 & 116.0 & 133.4 & 81.4 & 12.0 & 4.0 & 0.0 & 97.6 & 105.3 & 38.5 & 47.3 & 148.0 \\
1997 & 34.3 & 75.0 & 67.4 & 94.1 & 16.6 & 51.5 & 73.8 & 31.6 & 5.8 & 144.5 & 47.9 & 187.7 \\
1998 & 46.1 & 82.5 & 156.0 & 39.2 & 119.7 & 28.3 & 9.6 & 0.0 & 69.8 & 158.5 & 134.6 & 104.0 \\
1999 & 81.3 & 103.2 & 97.7 & 26.0 & 8.8 & 37.6 & 1.1 & 32.3 & 14.6 & 23.6 & 105.6 & 120.3 \\
2000 & 70.5 & 98.8 & 79.4 & 76.9 & 58.0 & 18.6 & 11.2 & 6.7 & 22.5 & 105.2 & 36.9 & 62.9 \\
2001 & 102.6 & 75.1 & 39.1 & 98.3 & 53.9 & 13.6 & 1.1 & 9.2 & 45.1 & 7.8 & 180.9 & 141.1 \\
2002 & 29.2 & 43.8 & 54.6 & 46.9 & 47.5 & 38.6 & 0.0 & 142.1 & 115.3 & 64.4 & 122.5 & 92.2 \\
2003 & 117.5 & 92.4 & 34.1 & 82.2 & 1.1 & 0.8 & 7.4 & 1.0 & 1.0 & 137.1 & 79.6 & 93.5 \\
2004 & 105.5 & 41.8 & 76.6 & 14.1 & 40.7 & 74.0 & 3.0 & 24.7 & 0.9 & 71.0 & 53.3 & 69.7 \\
2005 & 93.2 & 78.5 & 39.9 & 21.9 & 131.1 & 28.8 & 24.3 & 10.4 & 45.6 & 56.7 & 56.8 & 183.8 \\
2006 & 83.2 & 87.2 & 104.3 & 6.7 & 14.8 & 20.9 & 0.0 & 17.5 & 52.2 & 64.9 & 72.4 & 44.8 \\
\hline
\end{tabular}


numara olarak Tepecik Deresine (4) katıldığı, bu derenin de Büyükçekmece Gölüne dökülmekte olduğu görülür. Havza çıkıșı, $41^{\circ} 06^{\prime} 04^{\prime \prime}$ Kuzey enlem, $28^{\circ} 25^{\prime}$ 00" Doğu boylamlarında olup, denizden yüksekliği 110 m’dir. Havza içinde ve havzaya çok yakın olmak üzere 3 adet yağıș istasyonu, havza çıkıșında da akımı ölçmek üzere 1 adet akım ölçme savağı tesis edilmiștir. Havzaya ait 3 yağıș istasyonun 25 yıllık (1982-2006) yağıș verileri Thiessen Poligon yöntemi hesaplanarak, havzaya ait ortalama aylık yağıșlar Çizelge 1. de, aylık ortalama sıcaklık verileri de Çizelge 2 . de verilmiștir (Bakanoğulları, 2008).

\section{Standartlaștırılmıș yağıș indisi (SPI)}

SPI, McKee vd. (1993) tarafından kuraklığı tanımlamak ve izlemek amacıyla geliștirilmiștir. Sadece yağıș değerlerine bağı olarak hesaplanan indis yardımıyla kurak dönemin yanı sıra nemli dönemler de izlenebilir. SPI belirlenen bir zaman dilimi içinde, yağıșın ortalamadan olan farkının standart sapmaya bölünmesi ile elde edilir.

$$
S P I_{i, j}=\frac{X_{i, j}-X_{j}^{\text {ort }}}{O_{j}} \quad \text { Eșitlik } 1
$$

Eșitlik I'de, $X_{i, j}$, i ylıının j ayındaki yağıșı $(\mathrm{mm}), X_{j}^{\text {ort }} \mathrm{j}$ ayındáki ortalama yağıșı $(\mathrm{mm})$ ve $\mathrm{Q}$ ise yine $\mathrm{j}$ ayındaki yağıșın standart sapmasını göstermektedir. SPI değerleri farklı periyodlar (1, 3, $6,9,12,24,48$ ay gibi) için hesaplanabilir. Ancak yağıș verileri 12 ay ve daha kısa dilimlerde normal dağııma uymayabilir. Bu nedenle her bir veri seti Gamma fonksiyonuna uydurulur (Türkeș ve Tatll, 2008, Tatlı ve Türkeș, 2011 a.b.,Aksoy vd., 2018).

Çizelge 2. Damlıca deresi havzası aylık ortalama sıcaklık $\left({ }^{\circ} \mathrm{C}\right)$ verileri.

Table 2. Monthly average temperature ${ }^{\circ} \mathrm{C}$ / data of Damlica creek watershed.

\begin{tabular}{ccccccccccccc}
\hline Yll & Oca. & Șub. & Mar. & Nis. & May. & Haz. & Tem. & Ağu. & Eyl. & Eki. & Kas. & Ara. \\
\hline 1982 & 5.4 & 3.8 & 6.2 & 9.9 & 14.6 & 20.6 & 21.7 & 22.4 & 21.4 & 16.4 & 10.9 & 9.7 \\
1983 & 5.2 & 4.9 & 7.7 & 12.5 & 17.5 & 19.5 & 23.4 & 21.5 & 19.7 & 14.2 & 9.7 & 8.4 \\
1984 & 7.1 & 6.1 & 6.9 & 9.5 & 18.1 & 20.0 & 21.8 & 21.4 & 21.0 & 17.3 & 11.9 & 7.3 \\
1985 & 6.3 & 1.3 & 5.8 & 12.0 & 17.7 & 20.7 & 22.1 & 23.5 & 19.0 & 13.7 & 12.2 & 9.0 \\
1986 & 7.7 & 5.9 & 6.2 & 12.8 & 15.1 & 22.1 & 23.2 & 24.5 & 20.5 & 14.6 & 8.7 & 6.4 \\
1987 & 5.2 & 6.5 & 3.5 & 9.5 & 15.2 & 20.7 & 23.7 & 22.1 & 20.4 & 14.1 & 11.9 & 7.0 \\
1988 & 6.9 & 5.9 & 8.3 & 10.6 & 15.8 & 21.4 & 25.3 & 24.2 & 19.8 & 14.3 & 7.4 & 6.8 \\
1989 & 4.4 & 6.2 & 8.9 & 14.7 & 16.0 & 20.4 & 23.4 & 24.1 & 20.3 & 14.6 & 9.6 & 7.1 \\
1990 & 4.8 & 6.5 & 9.0 & 13.1 & 15.6 & 20.8 & 24.1 & 23.8 & 19.2 & 16.0 & 14.1 & 9.6 \\
1991 & 6.2 & 5.2 & 6.6 & 10.8 & 15.5 & 21.0 & 24.3 & 24.8 & 20.5 & 17.1 & 13.2 & 5.8 \\
1992 & 5.7 & 3.8 & 6.9 & 11.7 & 14.3 & 21.2 & 21.9 & 24.8 & 19.2 & 17.9 & 11.3 & 4.6 \\
1993 & 4.1 & 3.0 & 6.3 & 11.2 & 15.5 & 21.1 & 22.5 & 23.6 & 19.9 & 17.6 & 9.2 & 8.7 \\
1994 & 7.8 & 5.9 & 8.2 & 14.1 & 18.0 & 20.9 & 24.4 & 24.7 & 23.7 & 17.9 & 10.1 & 6.8 \\
1995 & 6.3 & 7.4 & 8.7 & 11.7 & 17.0 & 22.8 & 24.3 & 24.2 & 20.6 & 14.8 & 8.8 & 7.5 \\
1996 & 4.3 & 4.9 & 4.9 & 9.7 & 18.5 & 21.2 & 24.0 & 23.7 & 19.2 & 14.4 & 12.3 & 9.7 \\
1997 & 6.5 & 5.4 & 6.1 & 8.8 & 16.3 & 21.5 & 24.0 & 22.0 & 18.1 & 14.7 & 12.1 & 8.6 \\
1998 & 6.7 & 6.4 & 5.6 & 13.6 & 16.3 & 22.2 & 23.9 & 25.1 & 20.2 & 16.4 & 11.0 & 5.7 \\
1999 & 6.2 & 5.8 & 8.6 & 13.6 & 17.1 & 22.0 & 25.4 & 24.7 & 21.0 & 16.3 & 11.4 & 10.4 \\
2000 & 3.4 & 5.9 & 7.2 & 13.9 & 16.3 & 20.8 & 24.9 & 24.4 & 20.7 & 15.2 & 13.3 & 9.3 \\
2001 & 8.2 & 7.6 & 11.7 & 13.2 & 17.1 & 21.7 & 26.9 & 25.9 & 22.1 & 17.3 & 10.4 & 4.7 \\
2002 & 4.5 & 8.1 & 9.1 & 10.8 & 16.9 & 22.6 & 26.5 & 24.2 & 20.4 & 16.6 & 12.9 & 6.4 \\
2003 & 7.6 & 2.1 & 4.6 & 9.5 & 17.9 & 23.2 & 25.0 & 25.6 & 19.8 & 16.2 & 10.8 & 7.5 \\
2004 & 4.8 & 5.4 & 8.2 & 11.9 & 16.3 & 21.2 & 23.8 & 23.5 & 20.8 & 17.0 & 12.0 & 8.7 \\
2005 & 6.7 & 5.7 & 7.0 & 12.1 & 16.6 & 20.8 & 24.5 & 25.3 & 21.0 & 14.8 & 10.0 & 8.1 \\
2006 & 4.1 & 5.3 & 8.0 & 12.4 & 17.0 & 22.0 & 24.3 & 26.0 & 20.5 & 16.7 & 10.5 & 7.7 \\
\hline
\end{tabular}


Standartlaștırılmıș yağıș evapotranspirasyon indisi (SPEI)

SPEI ilk olarak Vicente Serrano vd. (2010) tarafindan bitki evapotranspirasyonu ve meteorolojik kuraklığı dikkate alarak tarımsal kuraklık șiddetinin değerlendirilmesi için geliștirilmiștir, hesaplanması kolaydır ve standart yağıș indisi (SPI) hesaplama temeline dayanır. SPEI aylık veya haftalık potansiyel evapotranspiransyon (PET) ile yağıș (P) arasındaki fark (D) olarak ifade edilir. Bu fark (D) analiz edilen ay (i) için su fazlası veya eksikliğidir ve Eșitlik 2 kullanılarak hesaplanır.

\section{$\mathrm{Di}=\mathrm{Pi}-\mathrm{PETi} \quad$ Eșitlik 2}

Thornthwaite (1948) yöntemine göre potansiyel ve gerçek evapotranspirasyonu hesaplamak için așağıdaki adımlar izlenmelidir

a) Her ayın ortalama sıcaklığına göre aylık sıcaklık indeksleri belirlenir.

$$
i=\left(\frac{t}{5}\right) 1.514 \quad \text { Eșitlik } 3
$$

Eșitlik 3`de; i, aylık sıcaklık indisi, t; ortalama aylık sıcaklık ( $\left.{ }^{\circ} \mathrm{C}\right)$ 'dır.

b) Her aya ait sıcaklık indeksleri toplanarak yıllık sıcaklık indisi bulunur.

$$
I=\sum_{k=1}^{12} i \quad k=1-12 \quad \text { Eșitlik } 4
$$

Eșitlik 4’de; I, yıllık sıcaklık indisi; i, aylık sıcaklık indisi k, ișlem yapılan aydır.

c) Potansiyel Evapotranspirasyon,

$$
\text { PET }=16 *(10 * t) / I^{\mathrm{a}} \quad \text { Eșitlik } 5
$$

Eșitlik $5^{`}$ de; PET, potansiyel evapotranspirasyon (mm/ay); t, or-talama aylık sıcaklık $\left({ }^{\circ} \mathrm{C}\right)$; I, yıllık sıcaklık İndeki; a, katsayı'dır ve Eșitlik (6) da hesaplama yöntemi verilmiștir.

$\mathrm{a}=\left(0.000000675^{*} P^{3}\right)-(0.000077$

$\left.{ }^{*} I^{2}\right)+(0.01792 * I)+0.49239 \quad$ Eșitlik 6

d) Düzeltilmiș Potansiyel Evapotranspirasyon (DPET, mm/ay), bulmak için, her aya ait evapotranspirasyon ile enlem düzeltme katsayısını çarpmak yeterli olmaktadır. Enlem düzeltme katsayısı (G), ortalama güneșlenme sürelerine göre değișen bir değerdir ve çizelge biçiminde Thornthwaite tarafından hazırlanmıștır.

$$
\mathrm{DPET}=\left(\mathrm{PET}{ }^{*} \mathrm{G}\right) \quad \text { Eșitlik } 7
$$

Araștırma havzasında her iki yöntem (SPEI ve SPI) ile bulunan sonuçlar Çizelge 3. de verilen kuraklık kategorilerine göre sınıflandırmıștır.

Çizelge 3. SPEI ve SPI kuraklık kategorisi

Table 3.Drought categories of SPEI and SPI

\begin{tabular}{rcc}
$\begin{array}{r}\text { SPEI \& SPI } \\
\text { Değerleri }\end{array}$ & $\begin{array}{c}\text { Kuraklık } \\
\text { Kategorisi }\end{array}$ & Sembol \\
\hline-2.00 & Așırı Nemli & AN \\
$1.50-1.99$ & Çok Nemli & ÇN \\
$1.00-1.49$ & Orta Nemli & ON \\
$0.50-0.99$ & Hafif Nemli & HN \\
$-0.49-0.49$ & Normale Yakın & NY \\
$-0.99--0.50$ & Hafif Kurak & HK \\
$-1.49--1.00$ & Orta Kurak & OK \\
$-1.99-1.50$ & Șiddetli Kurak & ȘK \\
$\leq--2.00$ & Așırı Kurak & AK \\
\hline
\end{tabular}

\section{BULGULAR VE TARTIȘMA}

Bu çalıșmada; Damlıca deresi havzasında 25 yıllık (1982-2006) iklimsel veriler ile SPI ve SPEI indisi ile yapılan kuraklık çalıșmasında yıllık kuraklık analizleri yapılmıștır (Șekil 2). Her iki indeks ile üç ve altı aylık kuraklık analiz sonuçları Șekil 4 ve 5 de verilmiștir. Her iki yöntem ile aylık kuraklık analizleri kuraklık șiddet kategorisine göre renk dağılımı ile Çizelge 4 ve 5 de ayrıntıı olarak verilmiștir.

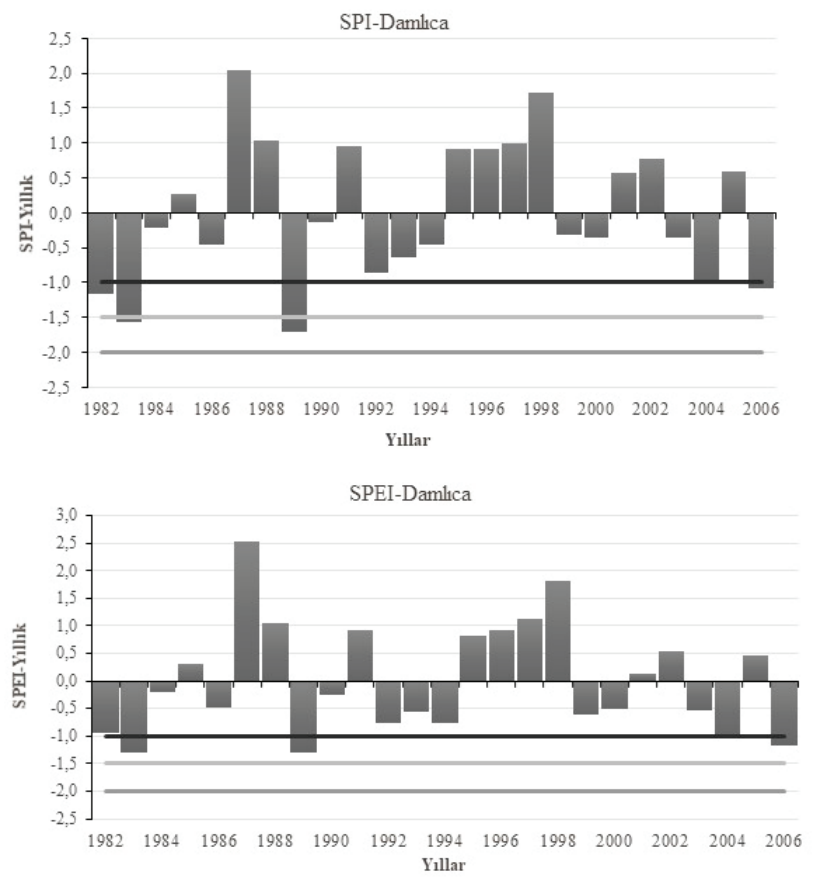

Șekil 2. Damlıca deresi havzası SPI ve SPEI yıllık zamansal değișkenlikler

Figure 2. SPI and SPEI annual temporal variability of Damlıca Watershed 
SPI indisi yıllık kuraklık analizinde (Șekil 2) Damlıca deresi havzasında 7 yıl kurak 10 yıl ıslak 8 yıl yıl normal yıl olarak belirlenmiștir. Kurak yılların açılımı șöyledir; 1992 ve 93 yılları hafif kurak, 1982, 2004 ve 2006 yılları orta kurak, 1983 ve 1989 yılları șiddetli kurak yıl kategorisinde yer almıștır. SPEI indisine göre ise yıllık tarımsal kuraklık yönünden incelendiğinde; 11 yıl kurak, 8 yıl nemli ve 6 yıl normal yıl olarak belirlenmiștir. Kurak yılların açılımı șöyledir; 1982, 1992, 1993, 1994, 1999, 2000 ve 2003 yılları hafif kurak, 1983, 1989, 2004 ve 2006 yılları orta kurak, yıl kategorisinde yer almıștır. Çamalan vd. (2017) Ülkesel ölçekte 123 meteoroloji istasyonuna ait (1971-2015) veri seti ile SPEI indisi kullanılarak 1, 3 ve 12 aylık dönemde kuraklık analiz yapmıș ve bu veriler ile küresel ölçekteki HadGEM2-ES modelinin RCP4.5 senaryosunun 2016 - 2098 periyodu bölgesel iklim kuraklık çıtıları ile ileriye dönük projeksiyonlar yapmıștır. Damlıca havzası gibi küçük ölçekte yapılan bu çalıșmalar yaygınlaștırılarak bölgesel tarımsal kuraklık projeksiyonları yapılabilir.

Havzanın 25 yıllık meteorolojik verileri ile yapılan yıllık SPI ve SPEI kuraklık verileri arasında yapılan değerlendirmede eğrisel korelasyon analiz sonuçları Șekil 3 de verilmiș, ikinci derece polinoma göre yıllık SPI ve SPEI kuraklık indeksleri arasında determinasyon katsayısı $\left(R^{2}\right) 0.98$ olarak belirlenmiș ve istatistiksel olarak anlamlı bulunmuștur. Tong vd. (2017) Çin'in kuzey bölgesindeki Xilingol otlaklarında 1961-2015 zaman periyodunda SPEI ve NDVI (Bitki vejetasyon indisi) ile aylık, mevsimlik, altı aylık ve yıllık kuraklık analizleri yapmıșlar yıllık SPEI ile NDVI arasında \%98 pozitif korelasyon bulmușlar kurak ve yarı kurak bölgelerde meteorolojik kuraklığın bitki vejetasyonu gelișimine olumsuz etki yaptığının belirtmișlerdir.

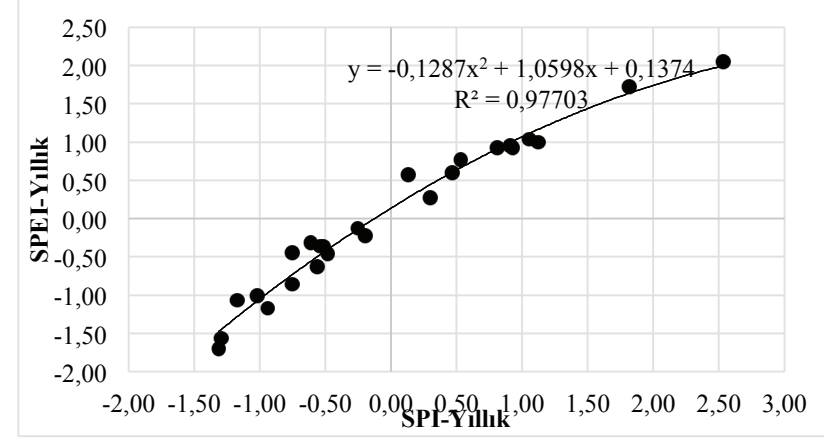

Șekil 3. Damlıca deresi havzası yıllık SPI-SPEI regresyon eğrisi ve denklemi

Figure 3. Regression plot of annual SPI versus annual SPEI for Damlica watershed
Mevsimsel kuraklık değerlendirmelerinde SPI indisine göre (Șekil 4); 1987, 1988, 1995, 1996. 1997 ve 2005 ylllarında dört mevsimin hiç birinde kuraklık görülmemișken gözlem yapılan diğer yılların hepsinde en az bir mevsim kurak geçmiștir. Kurak yıllarda 7 yıl kıș, 7 yıl ilkbahar, 8 yıl yaz ve 5 yıl sonbahar mevsiminde kuraklık belirlenmiștir. SPEI indisine göre (Șekil 4); 1987,1988, 1995, 1996 ve 1997 yıllarında dört mevsimin hiç birinde kuraklık görülmemișken gözlem yapılan diğer yılların hepsinde en az bir mevsim kurak geçmiștir. Kurak yıllarda 7 yıl kıș, 7 yıl ilkbahar, 8yılyaz ve 5 yıl sonbahar mevsiminde kuraklık belirlenmiștir. Nedealcov vd. (2015) 1980-2014 ölçüm periyodu için SPEI ve SPI indeksleri ile Moldova için kuraklığın 3 ve 6 aylık dilimlerde zamansal ve mekânsal dağılımlarını karșılaștırmıșlardır. Zamansal dağılımlarda her iki indisinde benzer șekiller verdiği, fakat kuraklık süre ve șiddetleri açısından SPEI değerlerinin sadece yağıșı değil evapotranspirasyonu da kullanması sebebiyle farklar olduğunu belirtmișlerdir. Keskiner vd. (2019) Seyhan havzasında 63 meteoroloji istasyonuna ait uzun dönem (1950-2006) aylık ve yıllık yağıș verileri ile SPI ve Normalin Yüzdesi İndisi (PNI) kuraklık indeksleri ile 5 ve 10 tekrarlama sürelerinde meteorolojik kuraklık haritaları olușturmușlardır. Böyle havza bazında kuraklık analizi çalıșmalarına SPEI indisinin eklenmesi, meteorolojik kuraklığın

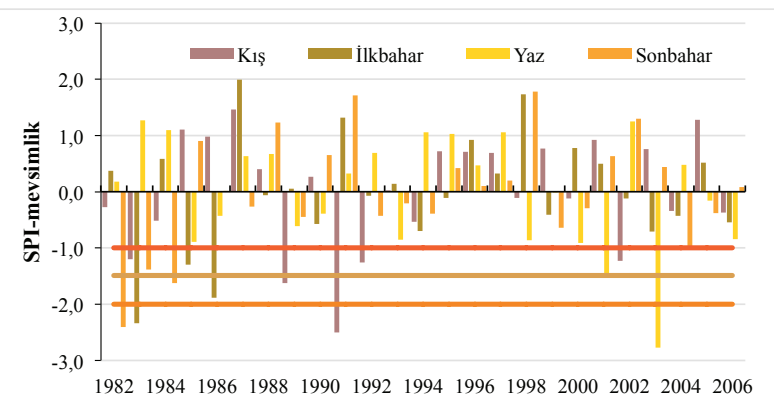

Yıllar

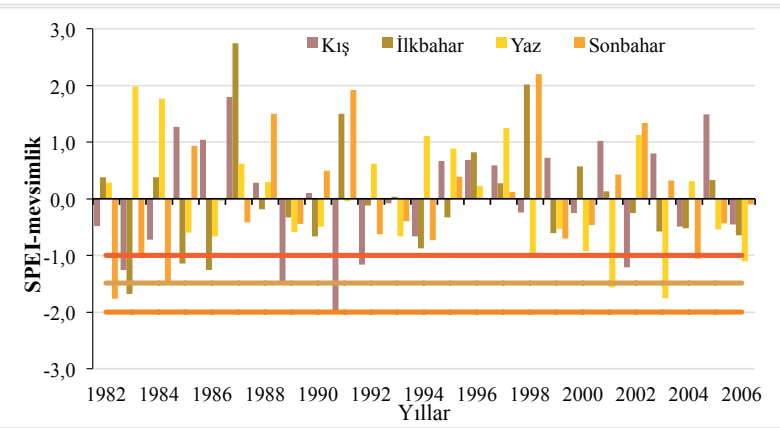

Șekil 4. Damlıca deresi havzası mevsimlik SPI ve SPEI zamansal değișkenlikler

Figure 4. Seasonal SPI and SPEI temporal variability of Damlica Watershed 
Çizelge 4. Damlıca deresi havzası SPI aylık kuraklık șiddetleri

Table 4. SPI monthly intensity of drought in Damlıca watershed

\begin{tabular}{|c|c|c|c|c|c|c|c|c|c|c|c|c|}
\hline YII & Oca. & Șub. & Mar. & Nis. & May. & Haz. & Tem. & Ağu. & Eyl. & Eki. & Kas. & Ara. \\
\hline 1982 & 0.43 & -1.11 & 0.06 & 0.90 & 0.32 & -0.67 & 0.83 & 0.44 & -0.55 & -0.61 & -1.54 & 0.24 \\
\hline 1983 & 0.31 & -0.09 & -2.97 & -0.98 & 0.27 & 1.10 & 0.82 & 0.88 & -0.31 & -0.38 & -0.52 & -1.89 \\
\hline 1984 & 0.63 & 0.24 & 0.66 & 0.81 & -0.03 & 0.61 & 0.74 & 1.04 & -1.16 & 0.07 & -1.41 & -1.64 \\
\hline 1985 & 1.50 & 0.66 & -0.12 & -0.15 & -1.95 & 0.02 & 0.24 & -0.99 & -0.07 & 0.77 & 1.06 & -0.90 \\
\hline 1986 & 1.26 & 0.41 & -1.25 & 0.21 & -2.76 & 0.57 & 0.02 & -2.15 & 0.30 & 0.84 & -1.16 & -0.06 \\
\hline 1987 & 1.27 & -0.61 & 1.83 & 0.70 & 0.27 & 0.04 & 0.87 & 0.68 & 0.20 & -0.41 & 0.59 & 1.22 \\
\hline 1988 & -0.81 & 0.03 & 0.09 & 0.74 & -0.28 & 0.89 & 0.86 & -2.15 & 0.26 & 0.36 & 1.74 & 1.25 \\
\hline 1989 & -1.17 & -3.29 & 0.30 & -1.97 & 0.84 & 0.21 & -1.68 & 0.27 & -0.33 & -0.39 & 0.60 & 0.30 \\
\hline 1990 & -2.02 & -0.25 & -1.93 & 0.26 & 0.64 & 0.60 & -1.68 & -0.12 & 0.81 & 0.08 & 0.76 & 1.45 \\
\hline 1991 & -1.30 & -0.33 & -0.13 & 1.19 & 1.07 & -0.23 & 0.79 & 0.56 & 1.10 & 1.48 & -1.00 & -1.54 \\
\hline 1992 & -1.93 & -2.10 & 0.43 & 0.25 & -0.15 & 0.59 & 0.97 & -0.41 & -0.16 & 0.32 & -0.18 & 0.64 \\
\hline 1993 & 0.11 & 0.56 & -0.23 & -0.12 & 0.83 & -2.20 & -0.25 & 0.64 & 0.32 & -3.00 & 1.10 & -0.03 \\
\hline 1994 & -0.35 & -0.50 & -0.52 & -0.47 & 0.52 & 0.91 & 1.06 & -0.35 & -2.94 & 0.20 & 0.31 & 0.37 \\
\hline 1995 & 1.23 & 0.18 & 0.63 & -0.03 & -0.41 & 0.30 & 1.14 & 0.20 & 0.91 & -0.58 & 0.67 & -0.31 \\
\hline 1996 & -0.75 & 1.14 & 1.08 & 0.83 & -0.44 & -1.62 & -1.68 & 1.17 & 1.13 & -0.39 & -1.00 & 0.80 \\
\hline 1997 & -0.79 & 0.51 & 0.21 & 1.03 & -0.22 & 0.68 & 1.00 & 0.63 & -0.56 & 1.08 & -0.98 & 1.28 \\
\hline 1998 & -0.39 & 0.65 & 1.28 & -0.16 & 1.13 & 0.14 & 0.17 & -2.15 & 0.89 & 1.19 & 1.03 & 0.08 \\
\hline 1999 & 0.37 & 0.97 & 0.68 & -0.72 & -0.65 & 0.40 & -0.71 & 0.64 & -0.02 & -0.93 & 0.56 & 0.38 \\
\hline 2000 & 0.18 & 0.91 & 0.42 & 0.76 & 0.64 & -0.23 & 0.23 & -0.12 & 0.23 & 0.73 & -1.48 & -0.94 \\
\hline 2001 & 0.68 & 0.51 & -0.48 & 1.09 & 0.59 & -0.52 & -0.70 & 0.03 & 0.64 & -2.17 & 1.60 & 0.70 \\
\hline 2002 & -1.00 & -0.27 & -0.05 & 0.08 & 0.50 & 0.42 & -1.68 & 1.35 & 1.19 & 0.18 & 0.84 & -0.16 \\
\hline 2003 & 0.86 & 0.81 & -0.65 & 0.85 & -2.05 & -3.07 & 0.06 & -1.04 & -1.57 & 1.02 & 0.01 & -0.13 \\
\hline 2004 & 0.72 & -0.33 & 0.37 & -1.56 & 0.40 & 1.01 & -0.30 & 0.51 & -1.68 & 0.29 & -0.77 & -0.73 \\
\hline 2005 & 0.55 & 0.58 & -0.45 & -0.96 & 1.20 & 0.16 & 0.55 & 0.09 & 0.64 & 0.04 & -0.65 & 1.24 \\
\hline 2006 & 0.40 & 0.73 & 0.76 & -2.58 & -0.30 & -0.13 & -1.68 & 0.34 & 0.72 & 0.19 & -0.18 & -1.63 \\
\hline
\end{tabular}

yanı sıra tarımsal kuraklığın da izlenmesine katkı sağlayacaktır.

Havzanın her iki kuraklık indisi yapılan 6 aylık kuraklık analizinde (Șekil 5); her iki yöntemde de yaz-sonbahar dönemlerinde kurak geçen yıl sayısı fazla olmuștur. Kıș-ilkbahar dönemleri daha az kurak geçmiștir.

Damlıca deresi havzasında aylar bazında SPI indisine göre (Çizelge 2) kuraklık değerlendirilmesinde; en șiddetli kurak ay 1989 yılı șubat ayı olmuștur. Bu ayı 2003 yılı haziran ve 1993 yılı ekim ayı takip etmiștir. Gözlem periyodunda kasım ayı 10 (1982, 1983, 1984, 1986, 1991, 1996, 1997, 2000, 2004, 2005) kez olmak üzere en fazla kurak geçen ay olmuștur. Bu ayı 8 kez kuraklık tekrarı ile ocak ayı, 7 șer kez temmuz ve aralık ayları takip etmiștir. Nisan ve mayıs ayları ise en az kuraklık belirlenen aylar olmuștur. SPEl indisine göre (Çizelge 3) aylık kuraklık değerlendirilmesinde; en șiddetli kurak ay, Șubat 1989, bu ayı 2003 yılı haziran ve 1989 yllı nisan

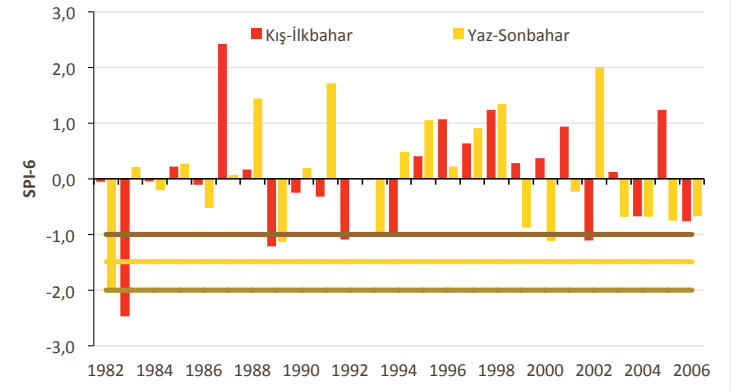
Yillar

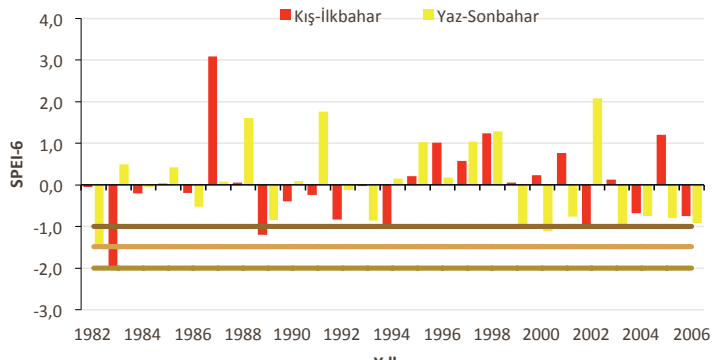

Yillar

Șekil 5. Damlıca deresi havzası SPI-6 ve SPEI-6 zamansal değișkenlikler

Figure 5. SPI-6 and SPEI-6 temporal variability of Damlica Watershed 
Çizelge 5. Damlıca deresi havzası SPEI aylık kuraklık șiddetleri

Table 5. SPEI monthly intensity of drought in Damlica watershed

\begin{tabular}{|c|c|c|c|c|c|c|c|c|c|c|c|c|}
\hline YII & Oca. & Șub. & Mar. & Nis. & May. & Haz. & Tem. & Ağu. & Eyl. & Eki. & Kas. & Ara. \\
\hline 1982 & 0.14 & -1.21 & -0.21 & 1.11 & 0.06 & -0.85 & 0.98 & 0.10 & -0.95 & -0.89 & -1.16 & -0.10 \\
\hline 1983 & & .42 & & & & & & & & & & \\
\hline 1984 & & -0.05 & 0.46 & & -0.76 & & & & & & & 1.33 \\
\hline 1985 & 26 & & -0.33 & & & & & & & & 0.91 & -1.03 \\
\hline 1986 & & 0.23 & -0.94 & & -0.90 & & & & & & & -0.24 \\
\hline 1987 & & & & & & & & & & & & \\
\hline 1988 & -0.96 & & & & רי & & & & & & 2.41 & 1.52 \\
\hline 1989 & -1.01 & -2.00 & -0.11 & & 0.96 & 0.04 & & -0.32 & -0.70 & & 0.46 & 0.11 \\
\hline 1990 & -1.26 & -0.66 & -1.25 & -0.16 & 0.56 & 0.68 & -0.82 & -0.48 & 0.89 & -0.28 & 0.41 & 1.78 \\
\hline 1991 & -1.13 & -0.67 & -0.37 & 1.67 & 1.86 & -0.58 & 0.43 & -0.09 & 1.81 & 2.59 & -1.03 & -1.21 \\
\hline 1992 & -1.30 & -1.62 & 0.15 & -0.07 & -0.36 & 0.47 & 1.56 & -0.74 & & -0.19 & -0.41 & 0.64 \\
\hline 1993 & -0.17 & 0.66 & -0.45 & -0.39 & 1.00 & -1.35 & -0.46 & 0.21 & -0.19 & -1.55 & 1.15 & -0.33 \\
\hline 1994 & -0.68 & -0.83 & -0.68 & -0.89 & 0.03 & 1.51 & 1.64 & -0.68 & -1.37 & -0.27 & 0.16 & 0.24 \\
\hline 1995 & 1.56 & -0.20 & 0.34 & -0.31 & -0.81 & -0.38 & 2.24 & -0.38 & 1.03 & -0.71 & 0.60 & -0.49 \\
\hline 1996 & -0.81 & 1.88 & & & & & -0.82 & & & & & 0.64 \\
\hline 1997 & & & & & & & & & & & & 1.48 \\
\hline 1998 & -0.68 & & & & & -0.46 & & & & & 0.96 & -0.05 \\
\hline 1999 & & & & & & & & & & & & 0.08 \\
\hline 2000 & -0.05 & & & & & & & & & & & -1.03 \\
\hline 2001 & 0.44 & 0.37 & -0.86 & & & & & & & & 2.02 & 0.75 \\
\hline 2002 & -0.93 & & & & & & & & & & 0.61 & -0.30 \\
\hline 2003 & 0.74 & & -0.60 & & & & -0.78 & & & & & -0.34 \\
\hline 2004 & 0.61 & -0.68 & & & & 1.68 & -0.68 & & & & -0.82 & -0.87 \\
\hline 2005 & 0.28 & 0.56 & -0.61 & & & -0.10 & -0.19 & & 0.24 & -0.23 & -0.63 & 1.45 \\
\hline 2006 & 0.18 & 0.89 & 0.58 & -1.47 & -0.73 & -0.70 & -0.85 & -0.56 & 0.50 & -0.21 & -0.32 & -1.32 \\
\hline
\end{tabular}

ayı takip etmiștir. Gözlem periyodunda temmuz ayı 12 kez, 1986, 1989, 1990, 1996, 1998, 1999, 2000, 2001, 2003, 2005, 2006 yıllarında olmak üzere en fazla kurak geçen ay olmuștur. Bu ayı 11 kez kuraklık ile ağustos ayı, 10 kez kuraklık tekrarı ile ocak, mayıs, eylül ve kasım ayları takip etmiștir. SPEl indisine göre tarımsal kuraklığın gözlendiği ay sayısı, SPI indisindeki meteorolojik kuraklık ay sayılarından oldukça fazla belirlenmiștir.

\section{SONUCLAR}

Bu çalıșmada, İstanbul Büyükçekmece içme suyu havzasında yer alan Çatalca- Damlıca deresi havzasında 1982-2006 yllı arası 25yıllık meteorolojik veriler kullanılarak havzada meteorolojik ve tarımsal kuraklık indekslerinde olan SPI ve SPEI indeksleri ile aylık, mevsimlik, 6 aylık ve yıllık kuraklık analizleri yapılmıș ve iki indeks değerleri karșılaștırılmıștır. 25 yıllık veri seti ile yıllık SPEI ve SPI Indeksleri arasındaki önemli bir korelasyon ( $r=0.977)$ bulunmuștur. YIllık değerlendirme sonuçlarına göre; SPEI indisi ile havzada 4 yıl orta kurak, 7 yıl hafif kurak. SPI indisi ile ise 2 yıl șiddetli, 3 yll orta kurak ve 2 yıl hafif kurak yll olarak tespit edilmiștir. SPEI indisine göre yıllık on yıllık süreler dikkate alındığında yıllık kuraklıklar daha ziyade 1990`lı yıllarda görülürken, aylık kuraklıkların 2000'li yıllarda daha sıklıkla oluștuğu görülmüștür. Bu iklimsel döngülerdeki değișimin bir göstergesi olabilir.

SPEI indisi aylık, 3 aylık, 6 aylık analizlerinde kuraklık kategori șiddetlerinde SPI indisi șiddet verilerine göre azalma görülmüștür. Ancak, bu indekste, sıcaklık ve evapotranspirasyon verilerinin de kullanılması ile daha hassas sonuçlar elde edilmiștir. Kuraklığın tarımsal yönden incelenmesi ve azaltılması açısından SPEI indisinin aylık, mevsimlik ve altı aylık kuraklık analizleri ile bölgede ekimi yapılan bitkilerin vejetasyon dönemlerine göre kuraklık analizlerinin yapılması daha gerçekçi ve sağlıklı sonuçlar verecektir. Her iki yöntemde de en az kuraklık görülen ay mart ayı olmuștur. 
SPEI indisi sonuçları ile SPI indisinin zayıf yönü olan toprak su bütçesi ile buharlașma / potansiyel buharlașma ISISI (ET/PET) sorunu giderilmeye çalıșılmıștır. Bu sayede havza bazında tarımsal kuraklıkların belirlenmesi ve gelecek kuraklık projeksiyonları için, bölgesel karar vericilerin daha doğru politikalar olușturulmasında bu yöntemin kullanılması yerinde olacaktır.

\section{KAYNAKLAR}

Aksoy H, Eriș E, Cetin M, Önöz B, Yüce Mi, Selek B, Aksu H, Burgan Hi, Eșit M (2018). Gediz havzasında kuraklık analizi. Uluslararası Katııımlı "Türkiye Ulusal Jeodezi Jeofizik Birliği (TUJJB) Bilimsel Kongresi", p. 28-31, 30 Mayıs-02 Haziran, İzmir-Türkiye.

Bae S, Lee SH, Yoo SH, Kim T (2018). Analysis of drought intensity and trends using the modified SPEI in South Korea from 1981 to 2010. Water: 10, 327, doi:10.3390/ w10030327.

Bakanoğulları F (2008). Çatalca-Damlıca deresi havzası yağıș ve akım karakteristikleri. T.C. Tarım ve Köyișleri Bakanlığı, Tarımsal Araștırmalar Genel Müdürlüğü, No: Tagem-BB-Topraksu-2008/64, Kırklareli.

Chen S, Zhang L, Liu X, Guo M, She D (2018). The use of SPEI and TVDI to assess temporal-spatial variations in drought conditions in the middle and lower reaches of the Yangtze River basin, China. Hindawi, Advances in Meteorology, Article ID 9362041, p.11, https://doi. org/10.1155/2018/9362041

Çaldağ B, Șaylan L, Toros H, Bakanoğulları F (2004). Drought analysis in northwest Turkey. Agroenvironment, p. 169-179, 20-24 October, Udine-Italy.

Çamalan G, Akgündüz AS, Ayvacı H, Cetin S, Arabacı H, Coșkun M (2017). SPEI indisine göre Türkiye geneli kuraklık değișim ve eğilim projeksiyonları. IV. Türkiye İklim Değișikliği Kongresi, TiKDEK 5-7 Temmuz, İstanbul.

Cetin M, Aksoy H, Önöz B, Eriș E, Yüce Mi, Selek B, Aksu H, Burgan Hi, Eșit M, Cavuș Y, Orta S (2018). Deriving accumulated precipitation deficits from drought severityduration frequency curves: A case study in Adana province, Turkey. 1st International Congress on Agricultural Structures and Irrigation, Proceeedings and Abstracts Book, ISBN 978605-81 136-0-2: 39-48, 26-28 September 2018, AntalyaTurkey.

Dai A (2011). Drought under global warming: A review. Wiley Interdiscip. Rev. Clim. Chang. 2: 45-65.

Gümüș V, Bașak A, Oruç N (2016). Standartlaștırılmıș yağıș indisi (SYi) yöntemi ile Șanlıurfa istasyonunun kuraklık analizi. Harran University Journal of Engineering 01: p.3644.

Heim RR (2002). A review of twentieth-century drought indices used in the United States. Bull. Am. Meteorol. Soc. 83: $1149-1165$.

Keskiner AD, Cetin M, Uçan M, Șimșek M (2016). Coğrafi bilgi sistemleri ortamında standardize yağıș indisi yöntemiyle olasılıkı meteorolojik kuraklık analizi: Seyhan Havzası Örneği.
Çukurova Tarım ve Gıda Bilimleri Dergisi, 31: 79-90.

Keskiner AD, Cetin M, Simsek M, Akin S, Cetiner I, (2019). Probabilistic regional meteorological drought analysis with standardized precipitation index and normal precipitation index methods in geographic information systems environment: A case study in Seyhan basin. Fresenius Environmental Bulletin, 28 (7): 5675-5688.

Koutroulis AG, Vrochidou AEK, Tsanis IK (2011). Spatiotemporal characteristics of meteorological drought for the island of Crete. J. Hydrometeorol., 12: 206-226.

Kwak JW, Lee, S.D., Kim, Y.S., Kim, H.S. (2013). Return period estimation of droughts using drought variables from standardized precipitation index. J. Korean Water Resour. Assoc. 46: 795-805.McKee TB, Doesken NJ, Kleist J (1993). The relationship of drought frequency and duration to time scales. In: Proceedings of the Eighth Conference on Applied Climatology, American Meteorological Society, Boston, MA: 179-184.

Nedealcov M, Raileanu V, Sirbu R, Cojocari R (2015). The use of standardized indicators (SPI and SPEI) in predicting droughts over the Republic of Moldova Territory. doi 10.1515/pesd-2015-0032 Pesd, Vol. 9 (2): 149-157.

Rossi G (2000). Drought mitigation measures: A comprehensive framework. In drought and drought mitigation in Europe; Voght, J., Somma, F., Eds.; Kluwer Academic Publishers: Dordrecht, the Netherlands, p.233246.

Stagge JH, Tallaksen LM, Gudmundsson L, Loonc AFV, Stahl K (2015). Candidate distributions for climatological drought indices (SPI and SPEI). International Journal of Climatology. 35: 4027-4040, doi: 10.1002/joc.4267.

Svoboda MD, LeComte D, Hayes M, Heim R, Gleason K, Angel J, Miskus D (2002). The drought monitor. Bull. Am. Meteorol. Soc. 83: 1181-1190.

Tatlı H, Türkeș M (2011a). Palmer kuraklık șiddeti ve standartlaștırımiș yağıș indislerinin Türkiye üzerinde karșılaștırılması. In: 5th Atmospheric Science Symposium Proceedings Book, p.231-239, 27-29 April 2011, İstanbul.

Tatlı H, Türkeș M (2011b). Türkiye'nin kurak ve nemli koșullarının model çıktı istatistiği (MOS) ile incelenmesi. In 5th Atmospheric Science Symposium Proceedings Book, p.219-229, 27-29 April 2011, İstanbul.

Thornthwaite CW (1948). An approach toward a rational classification of climate. Geogr. Rev. 38: 55-94.

Tong S, Bao Y, Te R, Ma O, Ha, Lusi A (2017). Analysis of drought characteristics in Xilingol grassland of Northern China based on SPEI and Its Impact on vegetation. Hindawi, Mathematical Problems in Engineering, p. 11, https://doi org/10.1155/2017/5209173.

Türkeș M, Tatı H (2008). Türkiye'de kuraklık olasılıklarının standartlaștııılmıș yağıș indisi (SPI) kullanılarak saptanması ve iklimsel değișkenlik açısından değerlendirilmesi. Küresel İklim Değișimi ve Su Sorunlarının Çözümünde Ormanlar Sempozyumu Bildiriler Kitabı (Ed. Ünal Akkemik), p.5562. Türkiye Ormancılar Derneği Marmara Șubesi, İstanbul Üniversitesi Orman Fakültesi, 13-14 Aralık 2007, Bahçeköy - İstanbul. 
Türkeș M, Tatlı H (2009). Use of the standardized precipitation index (SPI) and modified SPI for shaping the drought probabilities over Turkey. International Journal of Climatology, 29: 2270-2282. DOI: 10.1002/joc.1862.

Türkeș M (2014). Türkiye'deki 2013-2014 kuraklığının ve klimatolojik/meteorolojik nedenlerinin çözümlenmesi. Konya Toprak Su Dergisi 2: 20-34.

Türkeș M (2017). Türkiye'nin iklimsel değișkenlik ve sosyoekolojik göstergeler açısından kuraklıktan etkilenebilirlik ve risk çözümlemesi. Ege Coğrafya Dergisi 26 (2): 47-70.

Türkeș M (2019). Climate and drought in Turkey, Chapter 4. In Harmancioglu N B, Altinbilek D (Ed), Water Resources of Turkey. World Water Resources, 2. Springer, Cham, p.85125. https://doi.org/10.1007/978-3-030-11729-0_4.

Vicente-Serrano SM, Beguería S, López-Moreno JI (2010). A multiscalar drought index sensitive to global warming: The standardized precipitation evapotranspiration index. J. Clim. 23: 1696-1718.
Wilhite DA, Glantz MH (1985). Understanding the drought phenomenon: The role of definitions. Water Int., 10: 111-120.

Wilhite DA (2000). Drought as a natural hazard: Concept and definitions. In Drought: A Global Assesment; Wilhite, D. A., Ed.; Routledge: London, UK, pp: 3-18.

Wilhite DA, Svoboda MD, Hayes MJ (2007). Understanding the complex impacts of drought: A key to enhancing drought mitigation and preparedness. Water Resour. Manag. 21: 763-774.

Yürekli K, Ünlükara A (2013). Standartlaștırılmıș yağıș evapotranspirasyon indisi (SPEI) ile Tokat ilinin kuraklık analizi, III. Ulusal Toprak ve Su Kaynakları Kongresi, p.511-515, 1-4 Eylül, Tokat-Türkiye. 